\title{
Formulation and pH-Physical Stability Evaluation of Gel and Cream of Plantago major Leaves Extract
}

\section{Kartini, Babtista Merchyta Winarjo, Endang Wahyu Fitriani, Ridho Islamie}

Faculty of Pharmacy, University of Surabaya Jl. Raya Kalirungkut Surabaya 60294

Correspondence: Kartini

Email: kartini@staff.ubaya.ac.id

\begin{abstract}
Plantago major has been widely used for wound healing. This activityis supported byempirical as well as preclinical data. The aims of this study were to (1) formulate Plantago major leaves extracts (PMLE) into topical dosage forms i.e. creams and gels and; (2) evaluate the $\mathrm{pH}$ and physical stability of the products. The resultsshowed thatcreamsand gelsofPMLEwere able to maintain the $\mathrm{pH}$, visualappearance, flow properties, droplet size, and type of emulsion under accelerated $\left(40 \pm 2{ }^{\circ} \mathrm{C} ; 75 \pm 5 \%\right.$ RH for 1.5 months) as well as room temperature $\left(27^{\circ} \mathrm{C} ; 85 \%\right.$ RH for 1.5 months) stability testing conditions. However, viscosity of creams significantly changed under those conditions. Even though the viscosity of gels was unstable under accelerated condition, it was stable under room temperature storage. It is concluded that PMLE could be formulated into creams or gels dosage forms and further optimisation should be conducted.
\end{abstract}

Keywords: formulation; gels; creams; Plantago major; physical stability 


\section{Introduction}

Plantago major L. (Figure 1) is a perennial plant which belongs to the Plantaginaceae. Its height reach about $15 \mathrm{~cm}$, but the size varies a lot depending on the growth habitats. The leaves grow in rosettes, and they are ovate to elliptical with parallel venation. The leaves are glabrous and have an entire or irregularly dentate margin. The flowers are small, brownish-green on long non-ramified spikes [1].

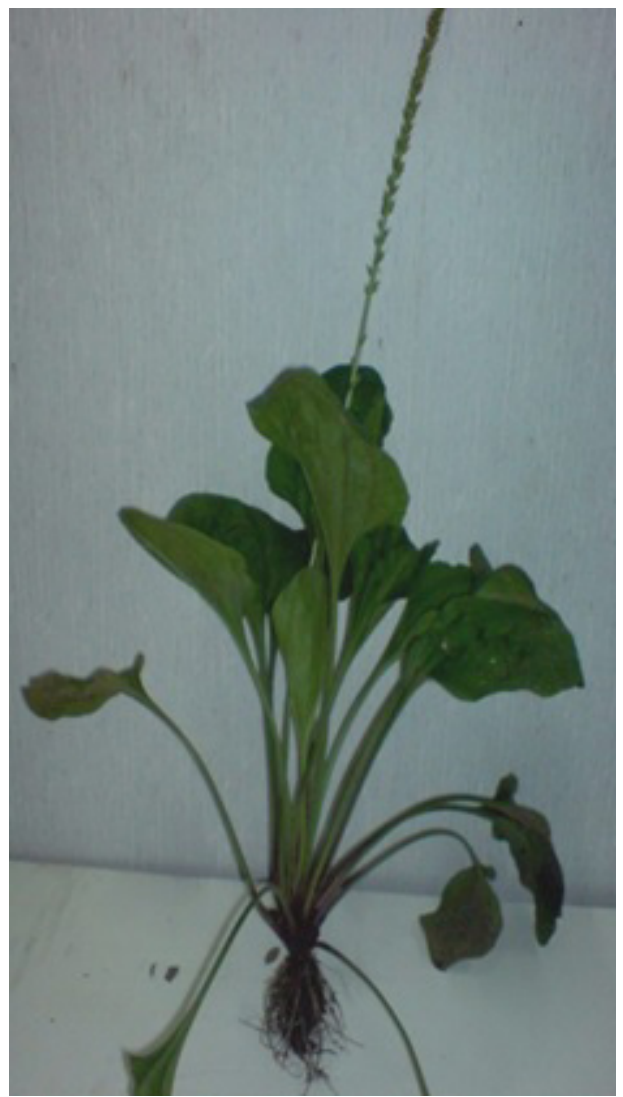

Figure 1. Plantago major L.

Plantago major is ubiquitous plant, including in Indonesia. This plant grows at a very wide range of regions, from 0 up to $3,300 \mathrm{~m}$ above sea level. However, most of them grow at $700 \mathrm{~m}$ above sea level or more. Their habitats include grasslands, agricultural areas, sides of roads and river side, forests and others, mainly on open fertile and rather hard land [2, 3].

More recent ethnopharmacological studies show that $P$. major is used in many parts of the world and in the treatment of a number of di- seases, such as: skin diseases, infectious diseases, problems concerning the digestive organs, respiratory organs, reproduction, the circulation, against tumors, for pain relief and for reducing fever. Furthermore, in skin diseases this plant empirically used for treatment of abcesses, acne, inflammation, bee, wasp and nettle stings, bruises, burn, cutaneous leishmaniasis, cuts, dermatitis, wound (as disinfectant, haemostatic), emollient, exanthema, poison ivy dermatitis, pruritus, pusformation in impetigo, rosen, soothing effect and wound healing [1].

Related with the wound healing activity, a number of researches have been conducted on $P$. major. Mahmood \& Phipps proved that an aqueous extract of $P$. major leaves stimulated wound healing in vivo using a rat model [4]. Leaf extracts of P. major showed enhancement of cell proliferation and migration in vitro [5]. Methanol and aqueous extracts of $P$. major leaves showed stimulating effects on the healing of burn wounds in rats [6]. Extracts of $P$. major leaves stimulated cell proliferation and migration in an in vitro scratch assay. Both ethanol and water extracts of fresh and dried leaves had stimulating effects which makes $P$. major an interesting source of different bioactive substances with wound healing potential. Polyphenol-rich ethanol-based extracts had stronger effects than water extracts [7]. Aucubin, one of chemical compounds of P. major, exhibited an oral wound healing effect on mice. Re-epithelization and matrix formation of the aucubin-treated group occurred earlier than that of the control group. In addition, the number of inflammatory cells of the aucubin-treated group was fewer than that of the control group. It was concluded that aucubin may be useful for oral wound healing and can be applied as a topical agent to oral wounds [8].

Considering the availability, empirically and scientifically uses, it is valuable to develop $P$. major extract as an "active compound" of herbal medicine products for wound healing. For this indication, $P$. major extracts can be formulated into topical dosage forms such as creams and 
gels. These dosage forms can be directly applied on wound and enable fast delivery of the active compound(s) to the site of action. In addition to efficacy, herbal medicine products have to comply the requirements of safety and quality. Quality of the products can be assured by stability tests. Therefore, the aims of this study were to [1] formulate Plantago major leaves extracts (PMLE) into topical dosage forms i.e. creams and gels and; [2] evaluate the $\mathrm{pH}$ and physical stability of the products.

\section{Method}

\subsection{Chemicals and equipments}

Chemicals used in this study were pharmaceutical grade, i.e.: cetyl alcohol, stearic acid, isopropyl palmitate, methylparaben, prophylparaben, sorbitan monostearate, sorbitol, polysorbate 60 , carbomer, $\mathrm{NaOH}, \mathrm{BHA}, \mathrm{BHT}$, and destilated water. Analytical grade solvent, ethanol, was procured from Merck KGaA (Darmstadt, Germany). Equipments used consited of climatic chamber (KBF 240), pH meter (Schott Lab 850), microscope (Olympus), analytical balance (Ohaus), viscometer cone and plate (Brookfield type cone and plate seri AT 71362), homogenizer (Multimix), mortar and stamper, waterbath (Memmert), exicator, and laboratory glass ware.

\subsection{Preparetion of extracts}

Air dried of Plantago major leaves were collected from Tawangmangu, Center of Java. Authentication of the plants (No. 1101/D.T/ XI/2013) was conducted by Center of Information and Development of Traditional Medicine, University of Surabaya, Indonesia. Crude drugs were powdered $(2 \mathrm{~mm})$ before use. Three hundreds $g$ of sample was macerated with $3 \times 1 \mathrm{~L}$ ethanol for $3 \times 24 \mathrm{~h}$. The ethanol extract was then evaporated under vacuum to yield a thick extract (10 g).

\subsection{Preparation of creams and gels of Plantago major leaves extracts (PMLE)}

Creams of PMLE was prepared using standard creams base according to Lachman with composition as shown on Table 1 [9]. Water phase (methylparaben, prophylparaben, sorbitol, polysorbate $60, \mathrm{BHA}$, and water) was dissolved in water and the oil phase (cetyl alcohol, stearic acid, isopropyl palmitate, BHT, and sorbitan monostearate) was melted on a waterbath. These two phases were gently mixed until cool and homogenous, then added gradually into PMLE.

Table 1. Composition of PMLE creams

\begin{tabular}{ll}
\hline Materials & Composition (\%) \\
\hline PMLE & 0.9 \\
Cetyl alcohol & 2.0 \\
Stearic acid & 20.0 \\
Isopropyl palmitate & 1.0 \\
Methylparaben & 0.1 \\
Prophylparaben & 0.01 \\
Sorbitan monostearate & 2.0 \\
Sorbitol & 3.0 \\
Polysorbate 60 & 1.5 \\
BHA & 0.02 \\
BHT & 0.1 \\
Destilated water to & 100 \\
\hline
\end{tabular}

Meanwhile, the standard gel base for PMLE was prepared according to Remington [10] with composition as shown on Table 2. Methylparaben was dissolved in hot water. After getting room temperatue, it was divided into two parts.

Table 2. Composition of PMLE gels

\begin{tabular}{ll}
\hline Materials & Composition (\%) \\
\hline PMLE & 0.9 \\
Carbomer & 4.0 \\
NaOH & 1.6 \\
Methylparaben & 0.3 \\
BHA & 0.02 \\
Destilated water to & 100 \\
\hline
\end{tabular}

The first portion was added by carbomer and then quickly stirred using high-speed stirrer. $\mathrm{NaOH}$ was dissolved subsequently to the second portion, and followed by BHA. Those solutions 
were mixed using high-speed stirrer. Finally, the gels base was added gradually into PMLE.

\section{4. $\mathrm{pH}$ and physical stability test}

$\mathrm{pH}$ and physical stability tests were carried out under accelerated ( 45 days; $40 \pm 2^{\circ} \mathrm{C} / 75 \pm 5 \%$ $\mathrm{RH})$ and long-term (45 days; $27 \pm 2^{\circ} \mathrm{C}$ ) testing. Parameters evaluated were $\mathrm{pH}$, visual appearance (color, odor, consistence), viscosity, flow properties, type of emulsion, and droplet size. The last two parameters are only applied for the creams.

\subsection{Statistical analysis}

All values were presented as mean \pm standard deviation, $n=3$. Data were analyzed by ANOVA followed by LSD Post Hoc Test when necessary using GraphPad Prism statistical software (GraphPad Software Inc., Sandiego, California, Windows Version 5.01). Differences were considered statistically significant at $\mathrm{P}<0.05$

\section{Result and discusssion}

\subsection{Visual appearance}

Visual appearance of PMLE creams and gels were evaluated every 15 days and the result is presented on Figure 2. Both of them did not show any visual degradation during 45 days as shown on Table 3. The creams and gels were able to maintain their consistence, green color, and characteristic odor.

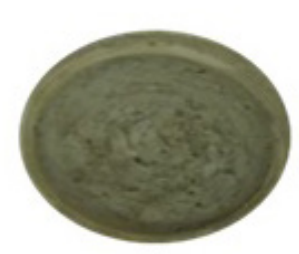

a

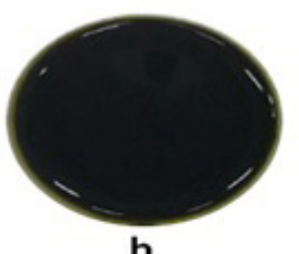

b
Figure 2. Creams (a) dan gels (b) of PMLE

\section{2. $\mathrm{pH}$}

$\mathrm{pH}$ of PMLE creams and gels are presented on Table 4. It is concluded that PMLE creams and gels were able to maintain the $\mathrm{pH}$ under accelerated and room temperature condition $(\mathrm{P}>0.05)$. A good topical preparation should have a suitable $\mathrm{pH}$ with the skin, i.e. 4.2-6.5 [11]. Therefore, PMLE creams with $\mathrm{pH}$ 4.33-5.71 is considered more suitable than PMLE gels. This dosage form should be further optimized since too alkaline gels will cause the skin to be scaly. At the other hand, if the $\mathrm{pH}$ is too acidic it will make the skin becomes irritated.

\subsection{Viscosity}

Viscosity is a physical properties of dosage forms which affect the flocculation rate. Flocculation may occur when there is an increase in viscosity too early. Table 5 indicated that creams was not stable under both accelerated and room temperature condition. At the other hand, viscosity of the gels did not significantly change under room temperature storage.

\subsection{Flow properties}

Flow properties of PMLE creams and gels can be seen on Figure 3 and 4. The flow properties of the PMLE cream and gel preparations are pseudoplastic, i.e. the viscosity will decrease with the increase of rate of shear [12].

\subsection{Type of emulsion and droplet size of PMLE creams}

PMLE creams showed oil in water $(\mathrm{O} / \mathrm{W})$ type emulsion (Figure 5), which was stable under storage condition. Changes in the average droplet size or globul size distribution are important parameter for evaluating an emulsion. Table 6 demonstrated that droplet size of PMLE creams was unchanging during observation.

\section{Conclusion}

Gels and creams of Plantago major leaves extracts were able to maintain stable $\mathrm{pH}$, visual appearance, flow properties, droplet size, and type of emulsion under accelerated stability testing condition $\left(40 \pm 2^{\circ} \mathrm{C} ; 75 \pm 5 \% \mathrm{RH}\right.$ for 1.5 months). However, viscosity of creams significantly changed under those conditions. 
Table 3. Visual appearance of PMLE creams and gels

\begin{tabular}{lllllll}
\hline Storage & $\begin{array}{l}\text { Dosage } \\
\text { form }\end{array}$ & $\begin{array}{l}\text { Para- } \\
\text { meters }\end{array}$ & Day* & & $\mathbf{0}$ & $\mathbf{3 0}$ \\
\cline { 4 - 6 } $\begin{array}{llll}\text { Accele- } \\
\text { rated }\end{array}$ & Creams & Consistence & Creams & Creams & Creams & Creams \\
& & Color & Green & Green & Green & Green \\
& & Odor & Characteristic & Characteristic & Characteristic & Characteristic \\
& \multirow{2}{*}{ Gels } & Consistence & Gels & Gels & Gels & Gels \\
& & Color & Green & Green & Green & Green \\
Room & & Odor & Characteristic & Characteristic & Characteristic & Characteristic \\
tempera- & & Consistence & Creams & & & Creams \\
ture & & Color & Green & & & Green \\
& & Odor & Characteristic & & Characteristic \\
& Gels & Consistence & Gels & & Gels \\
& & Color & Green & & Green \\
& & Odor & Characteristic & & Characteristic \\
\hline
\end{tabular}

*data were observed from three replications; Samples from room temperature storage were collected on day of 0 and 45 only.

Table 4. $\mathrm{pH}$ of PMLE creams and gels under stability testing conditions

\begin{tabular}{|c|c|c|c|c|c|c|}
\hline \multirow{2}{*}{$\begin{array}{l}\text { Dosage } \\
\text { form }\end{array}$} & \multicolumn{4}{|c|}{$\mathrm{pH}\left(40 \pm 2^{\circ} \mathrm{C} / 75 \pm 5 \% \mathrm{RH}\right)^{*}$} & \multicolumn{2}{|l|}{ pH $\left(27 \pm 2^{\circ} \mathrm{C}\right)^{*}$} \\
\hline & Day 0 & Day 15 & Day 30 & Day 45 & Day 0 & Day 45 \\
\hline Creams & $4.80 \pm 0.25^{\mathrm{a}}$ & $4.33 \pm 0.28^{\mathrm{a}}$ & $4.64 \pm 0.39^{a}$ & $5.10 \pm 0.71^{\mathrm{a}}$ & $5.11 \pm 0.31^{\mathrm{b}}$ & $5.71 \pm 0.48^{\mathrm{b}}$ \\
\hline Gels & $12.98 \pm 0.61^{\mathrm{c}}$ & $13.68 \pm 0.07^{c}$ & $12.80 \pm 0.44^{c}$ & $13.45 \pm 0.53^{c}$ & $13.44 \pm 0.06^{\mathrm{d}}$ & $13.46 \pm 0.04^{\mathrm{d}}$ \\
\hline
\end{tabular}

*data are presented as mean \pm SD, $n=3$ and the values with different superscript letters within a row in the same condition testing were significantly different (LSD Post Hoc Test, $\mathrm{P}<0.05$ ).

Table 5. Viscosity of PMLE creams and gels under stability testing conditions

\begin{tabular}{|c|c|c|c|c|c|c|}
\hline \multirow{2}{*}{$\begin{array}{l}\text { Dosage } \\
\text { form }\end{array}$} & \multicolumn{4}{|c|}{ Viscosity $\left(\mathrm{cP} ; 40 \pm 2^{\circ} \mathrm{C} / 75 \pm 5 \% \mathrm{RH}\right) *$} & \multicolumn{2}{|c|}{ Viscosity $\left(\mathrm{cP}, 27 \pm 2^{\circ} \mathrm{C}\right)^{*}$} \\
\hline & Day 0 & Day 15 & Day 30 & Day 45 & Day 0 & Day 45 \\
\hline Creams & $2240 \pm 1157^{\mathrm{a}}$ & $5170 \pm 752^{\mathrm{b}}$ & $3512 \pm 758^{c}$ & $2765 \pm 682^{\mathrm{d}}$ & $4272 \pm 1054^{\mathrm{e}}$ & $2825 \pm 134^{\mathrm{f}}$ \\
\hline Gels & $1950 \pm 733^{g}$ & $2780 \pm 124^{\mathrm{h}}$ & $2675 \pm 1165^{\mathrm{h}}$ & $3341 \pm 478^{\mathrm{i}}$ & $3086 \pm 851^{j}$ & $3720 \pm 646^{j}$ \\
\hline
\end{tabular}

*data are presented as mean $\pm \mathrm{SD}, \mathrm{n}=3$ and the values with different superscript letters within a row in the same condition testing were significantly different (LSD Post Hoc Test, $\mathrm{P}<0.05$ ).

Table 6. Droplet size of PMLE creams under stability testing conditions

\begin{tabular}{|c|c|c|}
\hline \multirow[t]{2}{*}{ Day } & \multicolumn{2}{|l|}{ Droplet size $(\mu \mathrm{m})$} \\
\hline & $40 \pm 2^{\circ} \mathrm{C} / 75 \pm 5 \% \mathrm{RH}^{*}$ & $27 \pm 2^{\circ} \mathrm{C}^{*}$ \\
\hline 0 & $6.83 \pm 0.03^{\mathrm{a}}$ & $0.81 \pm 0.02^{\mathrm{b}}$ \\
\hline 15 & $6.84 \pm 0.02^{\mathrm{a}}$ & - \\
\hline 30 & $6.83 \pm 0.03^{\mathrm{a}}$ & - \\
\hline 45 & $6.84 \pm 0.02^{\mathrm{a}}$ & $6.83 \pm 0.03^{b}$ \\
\hline
\end{tabular}

*data are presented as mean \pm SD, $n=3$ and the values with different superscript letters within a column were significantly different (LSD Post Hoc Test, $\mathrm{P}<0.05$ ). 

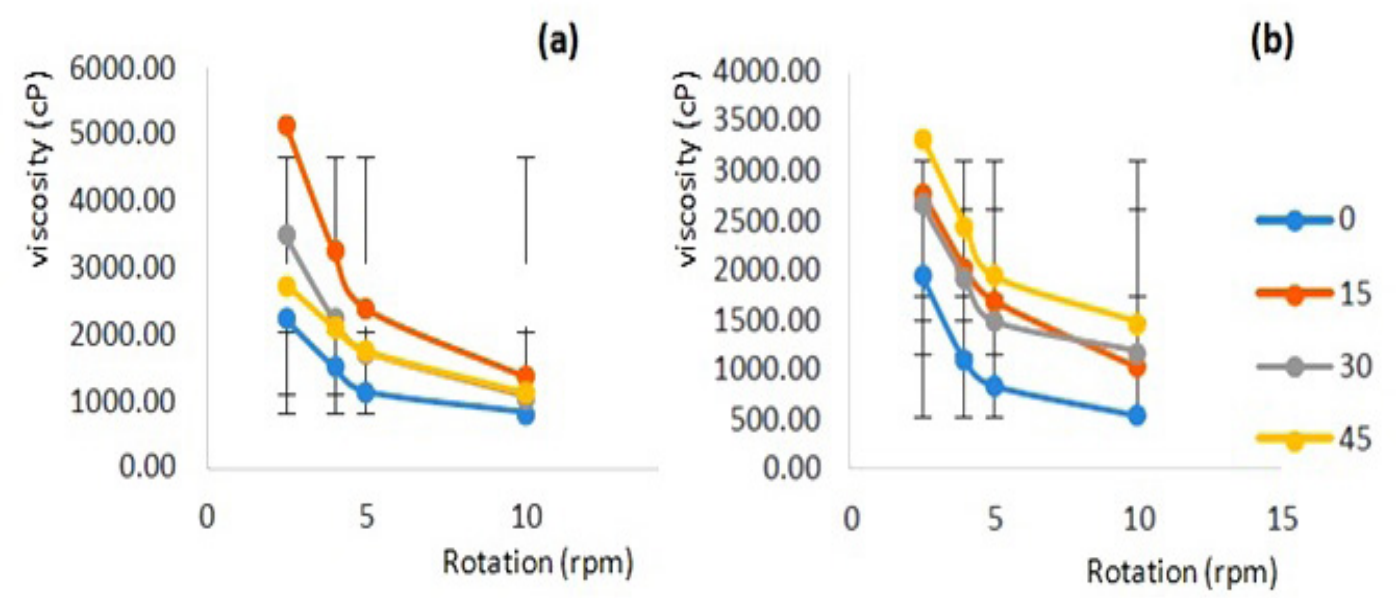

Figure 3. Flow properties of PMLE creams (a) and gels (b) under accelerated stability testing
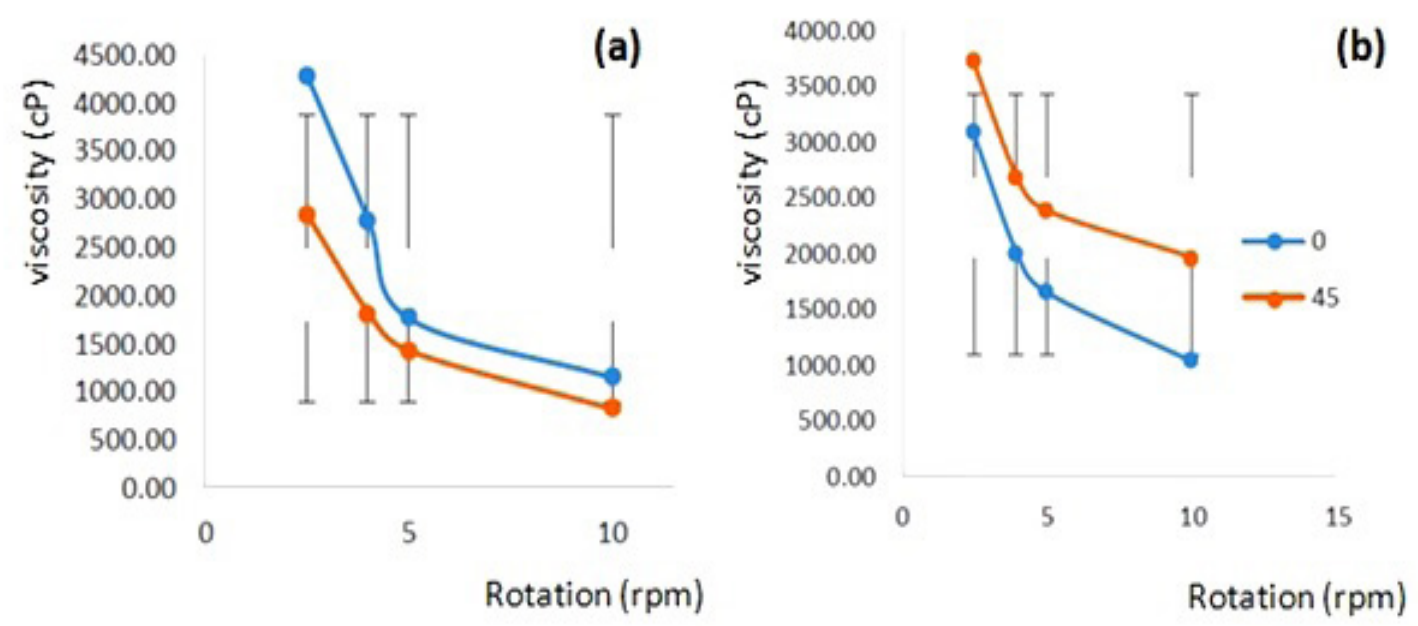

Figure 4. Flow properties of PMLE creams (a) and gels (b) under room temperature stability testing

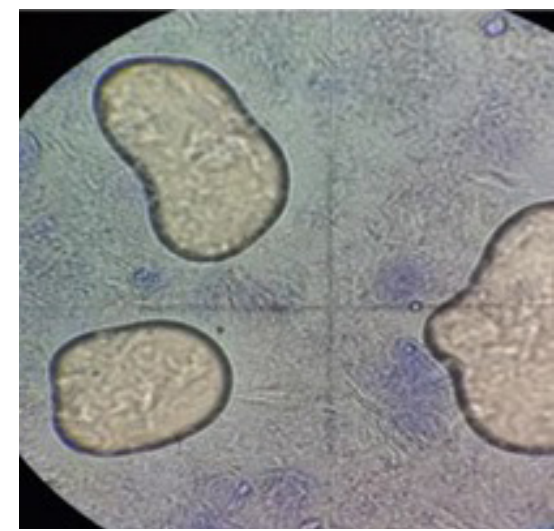

Figure 5. Oil in water $(\mathrm{O} / \mathrm{W})$ type emulsion of PMLE creams

Even though the viscosity of gels was unstable under accelerated condition, it was stable under room temperature storage. It is concluded that PMLE could be formulated into creams or gels dosage forms and further optimisation should be conducted.

\section{Acknowledgement}

This work was financially supported by 
Ministry of Research, Technology and Higher Education of the Republic of Indonesia, contract number: 120/SP2H/LT/DRPM/IV/2017.

\section{References}

1. Samuelsen AB. The traditional uses, chemical constituents and biological activities of Plantago major L. A review. Journal of Ethnopharmacology. 2000;71(1-2):1-21.

2. Sudarsono GD, Wahyono S, Donatus I. Purnomo. Tumbuhan Obat II Yogyakarta: Pusat Studi Obat Tradisional UGM. 2002.

3. Pangemanan L. Plantago L. . In: de Padua LS BN, Lemmens RHMJ editor. Plant Resources of SouthEast Asia. Bogor: PROSEA; 1999.

4. Phipps M, Mahmood A. Gastroprotective Activity of P. major in Rats. International Journal of Tropical Medicine. 2006;1(1):36-9.

5. Velasco-Lezama R, Tapia-Aguilar R, RománRamos R, Vega-Avila E, Pérez-Gutiérrez MS. Effect of Plantago major on cell proliferation in vitro. Journal of Ethnopharmacology. 2006;103(1):3642.

6. Amini M, Kherad M, Mehrabani D, Azarpira N, Panjehshahin M, Tanideh N. Effect of Plantago major on burn wound healing in rat. Journal of Applied Animal Research. 2010;37(1):53-6.

7. Zubair M, Ekholm A, Nybom H, Renvert S, Widen C, Rumpunen K. Effects of Plantago major L. leaf extracts on oral epithelial cells in a scratch assay. Journal of Ethnopharmacology. 2012;141(3):82530.

8. Shim KM, Choi SH, Jeong M-J, Kang SS. Effects of aucubin on the healing of oral wounds. In vivo. 2007;21(6):1037-41.

9. Lachman L, Lieberman HA, Kanig JL. The theory and practice of industrial pharmacy: Lea \& Febiger Philadelphia; 1986.

10. Remington JP. Remington: the science and practice of pharmacy: Lippincott Williams \& Wilkins; 2006.

11. Wasitaatmaja S. Penuntun Ilmu Kosmetik. Jakarta: UI Press; 1997.

12. Singh Y. Martin's physical pharmacy and pharmaceutical sciences. Department of
Pharmaceutics Ernest Mario School of Pharmacy Rutgers, The State University of New Jersey. 2006. 